\title{
Resilience in Early Childhood
}

\author{
Maesaroh Lubis' ${ }^{1}$ Rikha Surtika Dewi \\ Universitas Muhammadiyah Tasikmalaya \\ Corresponding Email :maesaroh.lubis@umtas.ac.id, rikha.surtika@umtas.ac.id
}

\begin{abstract}
Abstrak
Berbagai perubahan dalam situasi dan keadaan seorang individu akan disikapi beragam bergantung dengan bagaimana seorang individu tersebut memiliki kemampuan penyesuaian diri dalam berbagai situasi terutama situasi yang dianggap tidak menyenangkan atau penuh tekanan. Kemampuan penyesuaian diri tersebut tidak terbentuk begitu saja, banyak faktor yang mempengaruhi pembentukannya dan berproses sejak anak usia. Sejalan dengan tumbuh dan kembangnya seluruh aspek perkembangan, maka salah satu yang juga turut berkembang adalah kemampuan penyesuaian diri terhadap situasi tidak menyenangkan atau resiliensi, kemampuan kontrol diri, berempati, menghargai dan menghormati orang lain serta mampun menyemangati diri sendiri merupakan bentukbentuk resliensi. Membangun resiliensi pada anak usia dini tidak lepas dari peran serta orang tua atau keluarga melalui pengasuhan, lingkungan atau peran pendidik di sekolah dan karakteristik individu itu sendiri.
\end{abstract}

Kata kunci:

Resiliensi, Anak Usia Dini

\begin{abstract}
Various changes in the situation and circumstances of an individual will be responded to in various ways depending on how the individual has the ability to adapt in various situations, especially situations that are considered unpleasant or stressful. The ability to adjust is not formed just like that, many factors influence its formation and process since childhood. In line with the growth and development of all aspects of development, one that also develops is the ability to adapt to unpleasant situations or resilience, self-control, empathy, respect and respect for others and the ability to encourage oneself are forms of resilience. Building resilience in early childhood cannot be separated from the participation of parents or families through parenting, the environment or the role of educators in schools and the individual characteristics themselves.
\end{abstract}

Keywords:

Resilience, Early Childhood

\section{A. PENDAhuluan}

Perubahan dalam sebuah situasi dan keadaan merupakan suatu hal yang lazim kita alami disetiap fase kehidupan, perubahan cuaca, kondisi sosial, ekonomi, konflik, kehilangan atau yang paling sederhana adalah kekecewaan terhadap suatu hal. Sehingga manusia pada dasarnya dituntut untuk memiliki kemampuan untuk beradaptasi dengan berbagai perubahan tersebut agar dapat tetap memiliki kualitas kehidupan yang baik.
Dewasa ini kita dihadapkan pada berbagai situasi yang mana perubahan dan ketidakmenentuan menjadi bagian yang paling sering kita jumpai, salah satunya adalah pandemi covid 19. Situasi pandemi yang sudah berlangsung kurang lebih dua tahun lamanya, merupakan salah satu fenomena yang dapat menjadi sebuah gambaran bagaimana manusia berproses dan beradaptasi dari setiap fase yang dialaminya. Tidak sedikit perasaan takut, marah, sedih, karena 
kehilangan keluarga, pekerjaan, adanya perubahan dalam tatanan kehidupan menjadikan berbagai macam konflik dan tekanan psikologis bagi sebagian masyarakat. Namun seiring berjalannya waktu, tidak sedikit dari kita yang telah mampu melewati dan mulai bisa menerima berbagai situasi yang sulit ini sebagai sebuah kondisi yang memang harus dijalani dengan tetap memperhatikan kualitas kehidupan yang baik. Hal ini menunjukkan adanya kemampuan beradaptasi dan bernegosiasi dengan diri dan keadaan, meskipun begitu tidak semua individu memiliki kemampuan yang sama dalam beradaptasi atau menyesuaikan diri dengan situasi atau keadaan. Kemampuan seorang individu dalam menyikapi berbagai perubahan yang terjadi dalam kehidupanya sangat di pengaruhi dari bagaimana individu tersebut bertumbuh dan berkembang, lingkungan, serta peran orang tua atau keluarga dalam membentuk kemampuan penyesuaian diri tersebut atau dikenal dengan istilah resiliensi.

Resiliensi tidak hanya perlu dikembangkan pada individu dewasa karena setiap individu pasti mengalami masa-masa sulit dan tidak menyenangkan dengan versinya masing-masing, begitu juga anak-anak. Sejak dini anak perlu juga dikembangkan kemampuan resiliensinya, misalnya melalui kemampuan pengenalan pola emosi, kontrol perilaku dan pengendalian diri secara sederhana. Masten dan Gewirtz (2006) dalam penelitiannya mengenai perkembangan resiliensi khususnya yang paling penting ada pada fase anak usia dini, menurutnya sangat penting bagi anak-anak untuk memiliki kualitas perawatan yang baik dan kesempatan untuk belajar, nutrisi yang memadai dan dukungan keluarga serta masyarakat, untuk memfasilitasi perkembangannya baik dalam aspek keterampilan kognitif, sosial dan pengaturan diri. Anak usia dini dengan hubungan pengasuhan yang sehat dan stimulasi yang optimal cenderung memiliki potensi yang baik dalam memulai atau menawali fase kehidupan selanjutnya, misalnya untuk bersekolah atau bergaul di masyarakat. Anak-anak seperti itu biasanya menunjukkan ketahanan dalam menghadapi kesulitan, karena keterampilan dan hubungan perlindungan mendasar mereka terus beroperasi dan berkembang. Pada anak usia dini, sangat penting bahwa untu mereka memiliki perlindungan dan merasakan pengasuhan yang penuh kasih sayang, stimulasi dan nutrisi yang dibutuhkan untuk perkembangan otak yang sehat, kesempatan untuk belajar dan suasana yang menyenangkan serta diberikan ksesempatan untuk mengeksplorasi berbagai keterampilan baru untuk mengembangkan pengendalian dirinya. Penelitian serupa dari Miller-Lewis dkk (2013) yang mana dalam penelitiannya tentang faktor-faktor ketahanan kesehatan mental anak usia dini, memaparkan bahwa bagaimana konsep diri anak, kualitas hubungan anak dengan orang tua serta lingkungan dan kemampuan pengendalian merupakan faktor penunjang kesehatan mental anak usia dini yaitu terkait resiliensi. Resiliensi pada anak usia dini terbentuk seiring dengan tumbuh kembangnya, baik itu melalui pengasuhan oleh orang tua, lembaga pendidikan atau lingkungan sekitar anak.

Novita (2018) memaparkan dalam sebuhan penelitiannya tentang bagaimana peran orang tua sebagai pemeran utama dalam membangun resiliensi pada anak. Hal ini menunjukkan tentang bagaimana 
resiliensi atau kemampuan penyesuaian diri terhadap situasi yang penuh tekanan ini terbentuk sejak usia dini dan tidak terbentuk seketika saat seorang individu menjadi dewasa. Meskipun faktor lingkungan juga memiliki andil yang besar namun potensi ini perlu ditumbuhkan sejak dini, terutama oleh orang tua sebagai pendidik utama bagi anak-anak. Melalui interaksi dalam pengasuhan, bekerja sama dengan sekolah membangun karakter, sikap dan menstimulasi nilai-nilai serta kecakapan hidup anak. Penelitian lain dari Patilima (2013) memamparkan tentang bagaimana peran pendidik pos PAUD dalam membangun resiliensi anak, dan hasil yang diperoleh adalah para pendidikan pos PAUD menyumbang peran dalam membangun resiliensi anak teutama pada aspek keamanan dasar, yang mana keamanan dasar ini meliputi membangun kelekatan dengan anak; menjaga keamanan anak; membangkitkan semangat kebersamaan; dan menghargai orang lain. Mengacu pada penelitian ini diperoleh gambaran tentang bagaimana stimulasi dasar tingkat kemampuan resiliensi ini diperoleh sejak dini, tidak hanya oleh orang tua namun juga dalam lingkungan pendidikan anak. Mengacu pada berbagai penelitian sebelumnya, dapat ditarik kesimpulan tentang pentingnya membangun resiliensi sejak dini, oleh karena itu penting untuk dilakukan pengkajian berkelanjutan tentang berbagai upaya untuk menumbuhkan resiliensi pada anak usia dini.

\section{B. METODE}

Penelitian ini merupakan penelitian dengan menggunakan metode studi kepustakaan atau literatur review.
Literatur review merupakan ikhtisar komprehensif tentang penelitian yang sudah dilakukan mengenai topik yang spesifik untuk menunjukkan kepada pembaca apa yang sudah diketahui tentang topik tersebut dan apa yang belum diketahui, untuk mencari rasional dari penelitian yang sudah dilakukan atau untuk ide penelitian selanjutnya (Denney \& Tewksbury, 2013). Studi literatur bisa didapat dari berbagai sumber baik jurnal, buku, dokumentasi, internet dan pustaka. Metode studi literatur adalah serangkaian kegiatan yang berkenaan dengan metode pengumpulan data pustaka, membaca dan mencatat, serta mengelolah bahan penulisan (Zed, 2008 dalam Nursalam, 2016). Jenis penulisan yang digunakan adalah studi literatur review yang berfokus pada hasil penulisan yang berkaitan dengan topik atau variabel penulisan.

\section{HASIL DAN DISKUSI}

Resiliensi merupakan sebuah proses dari hasil adaptasi dengan pengalaman hidup yang sulit atau menantang, terutama melalui mental, emosional dan perilaku yang fleksibilitas, baik penyesuaian eksternal dan internal (VandenBos, 2015).pengertian lain tentang resiliensi dikemukakan oleh Grotberg (2001) yang menyatakan bahwa resiliendi merupakan kapasitas universal dari individu atau kelompok untuk mencegah, meminimalisasi, atau bahkan mengatasi efek yang merusak.. sehingga dapat disimpulkan bahwa resiliensi pada dasaranya merupakan kemampuan penyesuaian diri, antisasi dan kemampuan bangkit dari berbagai situasi yang dianggap kurang menyenangkan, buruk, menyedihkan, mengecewakan oleh seorang individu. 
Tingkat resiliensi setiap orang berbeda bergantung oada faktor faktor yang mempengaruhinya, baik yang berasal dari dalam dirinya sendiri ataupun dari luar dirinya. Resliensi juga bertumbuh dalam diri seseorang individu sejak anak-anak, menurut Novianti (2018) Resiliensi yang ditanamkan sejak usia dini akan membantu anak tumbuh dan berkembang menjadi individu yang dapat menghadapi berbagai permasalahan hidup dengan tegar dan bersikap optimis ketika sedang ditimpa kesulitan. Brooks \& Goldstein (2001) memaparkan bahwa resiliensi pada anak-anak meliputi kemampuan anak untuk mengatasi stres dan tekanan secara lebih efektif, mampu menghadapi berbagai tantangan yang ditemui sehari-hari, mampu bangkit kembali setelah mengalami kekecewaan, kemalangan, dan trauma, mengembangkan cita-cita yang jelas dan realistis, memecahkan masalah, memiliki hubungan yang nyaman dengan orang lain, dan memperlakukan dirinya sendiri serta orang lain dengan hormat.

Potensi membangun resiliensi sejak anak usia dini mengacu pada faktor-faktor pembentuk resliensi yang dikemukan Davis (1999), yaitu faktor resiko dan faktor pelindung. Faktor resiko dimaknai sebagi berbagai hal yang dapat menyebabkan dampak buruk atau menyebabkan individu beresiko untuk mengalami gangguan perkembangan atau gangguan psikologis, sehingga dapat disimpulkan bahwa faktor ini bersifat internal. Faktor yang kedua yaitu faktor pelindung, dimana faktor ini merupakan faktor yang bersifat menunda, meminimalkan, bahkan menetralisir hasil akhir yang negatif, dianataranya yaitu ada tiga faktor pelindung yang berhubungan dengan resiliensi pada individu, yaitu: faktor individual yang bersumber pada individu itu sendiri seperti karakteristik kepribadian, faktor masyarakat atau pengaruh lingkungan dan faktor keluarga dimana hubungan yang dekat dengan orangtua yang memiliki kepedulian dan perhatian, pola asuh yang hangat, teratur dan kondusif bagi perkembangan individu, sosial ekonomi yang berkecukupan, memiliki hubungan harmonis dengan anggota keluarga lain dapat menjadi dasar yang kuat membentuk resliensi pada diri individu tersebut.

Menurut NAEYC (National Association for The Education of Young Children), yang mengatakan bahwa anak usia dini adalah anak yang berada pada rentang usia o-8 tahun (Suyatno, 2005), sehinga dapat disimpulkan bahwa ini merupaka fase di awal-awal kehidupan individu sejak lahir. Fase ini merupakan fase yang dikenal denga istilah golden age atau masa emas, dimana di usia ini hampir seluruh aspek yang ada dalam diri individu berkembang dengan pesat dan optimal baik fisik-motori, kognitif-bahsa, sosialmoral dan emosi. Stimulasi yang tepat pada fase ini akan sangat menentukan bagaimana fase-fase kehidupan anak selanjutnya, karena fase ini dianggap sebagai pondasi. Mengacu pada pemikiran ini, bahwa tidak hanya tumbuh yang bertambah tinggi serta kemampuan belajar anak yang meningkat, namun juga keterampilan dalam pengembangan diri sebagai pribadipun turut berkembangan. Sehingga berkaitan dengan bagaimana anak memiliki karakteristik kepribadian, bakat minat, dan bahkan kecakapan hidup anak perlu perhatian yang optimal pada usia ini. Begitu juga halnya bagaimana kemampuan 
resiliensi, anak dapat melihat, mendengar dan mengamati berbagai hal yang ada di sekitarnya, bagaimana lingkungan meperlakukannya, pengasuhan seperti apa yang diterapkan kepadanya menjadi modal dasar terbentuknya resiliensi anak.

Menurut Reivich dan Shatte (2002), resiliensi terbentuk dari tujuh aspek dalam diri seseorang, yaitu sebagai berikut:

1. Emotion Regulation (Pengaturan Emosi)

Emotion Regulation adalah kemampuan seseorang untuk tetap berada pada keadaan tenang dan terkendali meskipun pada kondisi yang menekan. Dengan kata lain sejauhmana kita dapat mengendalikan

emosi khusunya emosi negatif ketika kita tengah mengalami kegagalan. Anak usia dini yang mampu mengenali respon emosi dalam dirinya akan lebih mudah melakukan pengaturan, misalnya dengan mengungkapkan bahwa dia sedih dan ingin menangis karena mainannya rusak atau saat dia senang saat dibelikan mainan baru. Dengan kemampuannya mengenali perasaannya tersebut secara tidak langsung dia melakukan pengelolaan dirinya agar lingkungan bisa memahaminya dan memberikan respon yang tepat.

2. Impuls Control (Pengendalian diri) Individu yang memiliki faktor pengendalian dorongan yang tinggi akan lebih mudah dalam pengaturan emosi. Kemampuan diri dalam mengatur dorongan, penting untuk menjaga agar setiap perilaku yang kita lakukan masih dalam kontrol dari diri sendiri dan tidak lepas kendali. Kemampuan pengendalian dorongan pada anak usia dini biasanya berkaitan erat dengan kemampuannya berkomunikasai, bagaimana dia mengkomunikasikan keinginan, bernegosiasi dengan dengan orang tua misal saat ingin membeli sesuatu, belajar mengantri, berbagi dan masih banyak lagi kegiatan sederhana yang jika dikenalkan dengan baik akan sangat berkontribusi membangun kemampuan pengendalian dorongan pada anak.

3. Optimist (Optimis)

Optimis adalah kepercayaan pada diri bahwa segala sesuatu akan dapat berubah menjadi lebih baik, mempunyai harapan akan masa depan dan percaya bahwa kita dapat mengontrol kehidupan seperti apa yang kita inginkan. Sikap optimis pada anak usia dini sangat erat kaitannya dengan bagaimana dia memperoleh timbal balik atau apresiasi dari lingkungan serta pemberian pemahaman mengenai pentingnya memiliki harapan dan tidak mudah menyerah, misalnya saat anak gagal dalam menyelesaikan sutau permainan. Tidak sedikit anak yang tidak dapat menyembunyikan rasa kecewanya, maka diperlukan peran orang tua untuk membesarkan hatinya untu tidak menyerah dan mencoba lagi, serta memberikan apresiasi saat anak melakukannya. Disini anak akan belajar memahami tentang bagaimana membangun harapan dan optimis bahwa saat dicoba kembali bisa sesuai dengan harapannya.

4. Causal Analysis (Analisis Penyebab Masalah)

Analisis penyebab masalah adalah kemampuan untuk mengidentifikasi penyebab dari 
sebuah peristiwa yang dialami. Hal ini penting untuk menjaga diri kita agar tidak mengambil tindakan yang salah dan merugikan diri sendiri ataupun orang lain. Anak usia dini juga perlu distimulasi terkait bagaimana dia mengenali sebab akibat dan melakukan analisis secara sederhana. Tentunya tidak berkaitan dengan permasalahan yang kompleks melainkan melalui kegiatan sederhana yang dilakukannya, misalnya saat anak tanpa sengaja menginjak mainan hingga rusak, orang tua bisa mengenalkan konsep merapihkan mainan setelah selesai digunakan, agar tidak berantakan di lantai dan terinjak dan melukai kaki. Jika dikomunikasikan dengan cara yang tepat dan konsisten dilakukan maka pemahaman anak terkait analisis penyebab masalah akan terbentuk.

5. Empathy (Empati)

Empati adalah kemampuan untuk turut merasa atau mengidentifikasi diri dalam keadaan, perasaan atau pikiran yang sama dengan orang lain atau kelompok lain. Empati membantu kita untuk peka terhadap perasaan orang lain dan mengurangi risiko terjadinya konflik. Empati sangat erat kaitannya dengan kepekaan kita terhadap lingkungan, begitu juga bagaimana empati dapat terbentuk pada anak usia dini. Sering mengajak anak berkomunikasi dan bercerita tentang apa yang di rasakannya, apa yang kita rasakan, mencoba mengenali perasaan tokoh di film kartun melalui ekpresi wajahnya, dapat sangat membantu membentuk kemampuan empati pada anak usia dini.
6. Self-Efficacy (Efikasi Diri)

Efikasi diri menggambarkan sebuah keyakinan bahwa individu dapat memecahkan masalah dan dapat meraih kesuksesan. Dengan adanya keyakinan ini, kita menjadi termotivasi untuk memecahkan masalah dan yakin bahwa masalah yang dihadapi mampu untuk dilewati. Kemampuan efikasi diri sangat penting bagi individu sebagai bentuk optimisme terhadap apa yang dilakukan, anak usia dini yang diberikan keleluasaan dan kesempatan dalam mengeksplorasi dirinya dalam berbagai kesempatan kegiatan akan memiliki efikasi diri yang jauh lebih baik dengan anak yang sering dilarang atau tidak di ajak melakukan hal-hal baru. Pengalaman yang pernah dibnagunnya tersebut dapat menjadi modal penting bagaimana dia akan memiliki rasa mampu diri atau yakin akan kemampuannya sendiri.

7. Reaching out (Kemampuan untuk meraih apa yang diinginkan)

Individu yang mampu untuk memperbaiki dan mencapai keinginan yang dituju, maka akan memiliki aspek yang lebih positif. Apabila kita takut gagal sebelum mencoba , kita tidak akan mendapat apa yang kita inginkan. Anak usia dini yang memiliki pengalaman keberhasilan yang menyenangkan, cenderung akan tidak takut mencoba dan akan lebih bersemangat untuk mencapai keberhasilan-keberhasilan lainnya. Namun menciptakan pengalaman keberhasilan yang menyenangkan ini tidak akan begitu saja diperoleh tanpa ada dukungan dari orang tua atau lingkungan, dengan pemberian apresiasi dan reward 
sebagai penguatan terhadap perilakunya tersebut atau keberhasilannya dengan begitu anak akan semakin termotivasi untuk memiliki dorongan untuk meraih apa yang diinginkan dan di cita-citakan.

Brooks dan Goldstein (2001) memaparkan tentang sepuluh sikap yang perlu dimiliki oleh orang tua, untuk membentuk resliensi pada anak, yaitu:

1. Berempati. Disini orangtua diharapkan untuk dapat menempatkan dirinya pada posisi anak dan melihat dunia melalui sudut pandang mereka sendiri.

2. Berkomunikasi efektif dan mendengarkan secara aktif melibatkan aktifitas mendengarkan efektif terhadap apa yang disampaikan anak, memahami dan memastikan kembali apa yang anak coba sampaikan serta memberi respon dengan cara menghindari cara-cara yang dapat membuat mereka tidak nyaman,.

3. Merubah skenario negatif bila ada suatu kondisi atau perintah dalam waktu tertentu yang tidak dilakukan oleh anak, makaorang tua akan mengubah 'skenarionya' sehinggaanak pun mengubah perilakunya tersebut.

4. Mencintai anak agar mereka merasa istimewa dan dihargai dengan cara mengarahkan anak untuk lebih produktif, memberikan kesempatan mencoba dan tidak meremehkan kemampuan mereka.

Menerima anak apa adanya dan membantu mereka memiliki citacita yang realistis

5. Membantu anak meraih keberhasilan dengan mengidentifikasi dan memperkuat kompetensinya.
6. Membantu anak menyadari bahwa kesalahan adalah pengalaman yang bisa menjadi pelajaran melalui diskusi dan pengalaman berkegiatan.

7. Mengembangkan tanggung jawab dan kepekaan sosial dengan memberi kesempatan untuk merasakan keberhasilan, terutama dalam membuat perubahan positif bagi dunia. Mengajarkan pada anak memecahkan masalah dan membuat keputusan anak membantu anaknya belajar bagaimana cara membuat keputusan dan memecahkan masalah secara mandiri,

8. Mendisiplinkan anak dengan cara yang mengembangkan disiplin diri dan penghargaan pada diri sendiri.

Sedangkan terkait peran lembaga pendidikan anak usia dini dinilai lebih banyak mengembangkan aspek kompetensi sosial yang mengarah pada kemampuan otonomi anak, kontrol diri, semnagat atau motivasi serta kemampuan memberikan perhatian bagi orang lain, sejalan dengan penelitian yang dilakukan oleh Patilima (2013) tentang bagaimana peran pendidik di pos PAUD menumbuhkan resiliensi pada anak melalui berbagai kegiatan. Pendidik berupaya agar anak ikut serta pada setiap kegiatan bermain yang menyenangkan, sehingga ia tidak merasa sendiri, mendorong anak untuk bermain; mengeksplorasi pengetahuan dan pemahaman anak melalui bahasa; Memberi fasilitas kepada anak untuk berprestasi; memberikan keleluasaan anak bermain memfasilitasi anak untuk bersahabat; mendorong anak untuk bersahabat; mendorong anak menggali minat dan bakatnya; memfasilitasi minat dan bakat anak; mendorong imajinasi anak. Berbagai 
upaya tersebut terintegrasi dalam seluruh kegiatan selama anak berada di pos PAUD.

Berbeda dengan individu dewasa, perkembangn resiliensi bagi anak usia dini menjadi terlihat lebih kompleks karena berbagai pihak dapat terlibat serta proses yang terjadi berdampingan dengan bagaiman anak ini tumbuh dan berkembang, dengan kata lain stimulasi sekecil apapun dapat berpengaruh terhadap seluruh aspek perkembangan anak salah satunya yang akan turut mengikuti adalah kemampuan anak mengembangkan resiliensinya. Terjadi secara alami, mengikuti hakikat anak usia dini dimana aktivitas utamanya adalah bermain, maka resiliensi akan juga terbentuk melalui kegiatan bermain tersebut. Santrock (2007) bahwa karakter resiliensi anak bersumber dari individu, keluarga inti, dan pihak di luar keluarga. Orang tua menjadi tokoh utama dalam menciptakan stimulasi seperti apa yang diberikan kepada anak baik melalui pengasuhan secara langsung maupun dalam memberikan keleluasaan anak mengeksplorasi dirinya serta kerjasama dengan lembaga PAUD. Anak dengan resiliensi yang baik akan cenderung memiliki kontrol diri dalam berbagai situasi sosial dan mampu membangun empati serta mengbangun rasa hormat, menghargai orang lain dan tentunya kemampuan dalam menyesuaikan drii. Seperti yang di kemukakan olehBronfenbrenner (1979), anak yang resilien adalah anak yang mampu menyesuaikan diri dengan lingkungan (Schoon, 2006: 95).

\section{KESIMPULAN}

Membangun kemampuan resliensi pada anak usia dini merupakan bagian dari perkembangan anak itu sendiri, dimana melalui pengasuhan dan peran serta lembaga PAUD memiliki peranan penting bagaimana terbentuknya resiliensi pada anak usia dini. Anak usia dini dengan kemampuan resilieni yang baik akan menunjukan kemampuan kontrol diri yang baik, empati, kemampuan menghargai dan menghormati orang lain, serta mampu menyemangati dirinya dari kegagalan sehingga tidak meudah menyerah. Resiliensi ini merupakan suatu kemampuan yang perlu dikembangkan sejak dini bagi individu agar dapat menyesuaikan diri dengan berbagai situasi, terutama situasi yang dianggap kurang menyenangkan, dengan resiliensi yang baik individu akan dapat melewati situasi tersebut dengan baik.

\section{DAFTAR PUSTAKA}

Brooks, Robert., Goldstein, Sam. 2001. Raising Resilient Children. McGraw-Hill.

Brooks, Robert., Goldstein, Sam. 2005. Handbook of Resilience in Children. Springerlink

Davis, N.J. (1999). Resilience: Status of research and research-based programs. Working paper, Center for Mental Health Services, Substance Abuse and Mental Health Services Administration, U.S. Department of Health and Human Services; Rockville

Denney, A. S., \& Tewksbury, R. (2013). How to write a literature review. Journal of criminal justice education, 24(2), 218-234.

Hamid Patilima. 2015. Resiliensi Anak Usia Dini. Alfabeta: Jakarta

Grotberg, E. H. (2001). Resilience programs for children in disaster. Ambulatory Child Health. https://doi.org/10.1046/j.1467o658.2001.00114.X 
Masten, A.S \& Gewirtz, A.H.20o6. Resilience In Development: The Importence Of Early Childhood. Ensyclopedia On Early Childhood Development. Centre of Excellence for Early Childhood Development-University of Minnesota, USA.

Miller-Lewis et al. 2013. Resource factors for mental health resilience in early childhood: An analysis with multiple methodologies. Child and Adolescent Psychiatry and Mental Health, $7: 6$ http://www.capmh.com/content/ $7 / 1 / 6$

Reivich, K. and Shatté, A. 2002. The Resilience Factor: 7 Essential Skills for Overcoming Life's Inevitable Obstacles. Broadway Books.

Suyanto, Slamet. (2005). Konsep Dasar Pendidikan Anak Usia Dini. Jakarta: Dikti Depdiknas.

VandenBos (2015). APA dictionary of psychology, second edition, USA: American Psychological Assosiation

Wolin, S. J., \& Wolin, S. (1993). The Resilient Self How Survivors of Troubled Families Arise above Adversity. New York Villard Books.

Zed, Mestika. 20o8. Metode Penelitian Kepustakaan. Jakarta : Yayasan Obor Indonesia. 